\title{
Culinary Tourism Phenomenon in Cirebon
}

\author{
Myrza Rahmanita, Rina Suprina \\ Sekolah Tinggi Pariwista Trisakti \\ Jakarta, Indonesia \\ myrzarahmanita@stptrisakti.ac.id
}

\author{
H. Peri Puarag \\ Universitas Tujuh Belas Agustus \\ Cirebon, Indonesia \\ puaragperi@yahoo.com
}

\begin{abstract}
Enjoying a typical food in Cirebon is one of the tourism activities carried out by the tourists when visiting Cirebon. Therefore, this study aims to determine the phenomenon of culinary tourism in Cirebon, especially from the visitors' perspective. Things observed among other are visitor characteristics, favorite typical food, the choice of places to taste the food, and visitors opinion on matters related to culinary tourism. The method used is descriptive method which aims to depict the phenomenon under study. Data was collected using a questionnaire where visitors were asked to fill it by giving a check mark in the appropriate answers according to their opinion. The data were processed statistically by calculating the frequency, mean value, standard deviation, and cross tabulation. The results showed the respondents demography, the most favorite typical food namely Empal Gentong, the respondents preference to visit local restaurant instead of traditional market and food festivals, and their attitude regarding culinary tourism.
\end{abstract}

\section{Keywords - Culinary, Tourism, Cirebon}

\section{INTRODUCTION}

Cirebon has various tourism potentials such as historical places and cultural treasures. Historical places include the palace such as Kasepuhan, Kanoman and Kacirebonan, Meanwhile, cultural treasures include art and creative works such as batik with typical patterns from Cirebon, artists and mask dance, puppet show and glass painting. Adding to the cultural richness of Cirebon is its local culinary such as tahu gejrot, empal gentong, nasi Lengko etc. Seeking typical food is one of the activities tourists usually do when visiting Cirebon. Furthermore, empirical data shows that not only the tourists are hunting for typical food and souvenirs 1 of Cirebon, but also the locals love their local food and often eat out to get their typical cuisine as part of their customs or their lifestyle. Seeking a unique and memorable eating and drinking experience while travelling is simply defined as culinary tourism. According Saptatyningsih (2003) spending money for food and drink in tourism world is the second largest expenditure after the accommodation whose contribution reached $38.48 \%$. Tourism activities related to food and beverages, known as a food tourism is experiencing rapid development in the tourism industry nowadays. Now the food is not merely to fulfill human's need when hungry but also to provide further role in society. Long (1998) states that "Food is a significant means to penetrate into another culture as" ... it allows an individual to experience the 'other' on a sensory level, and not just an intellectual one ". Symons (1999) stated that "local food is a fundamental component of a destination's attributes, adding to the range of attractions and the overall tourist experience."

The development of culinary tourism in Indonesia including Cirebon is characterized by the rapid growth of restaurants and other food places with their own qualifications and characteristics. Various courses are offered ranging from traditional regional specialties to the modern fast foods. However, we have not found a lot of information and research on the culinary tourism in Cirebon in terms of the purpose of people coming to the restaurants, which place to eat they prefer, what activities they do and which elements play the most significant roles in culinary tourism in Cirebon. This research is limited to discussing culinary tourism phenomena in Cirebon based on the visitors perspective.

\section{LITERATURE REVIEW}

There is still debate about the definition of culinary tourism. Several other definitions often considered the same or being used interchangeably with culinary, such as food, gastronomy, etc. Within this paper both terms are differentiated, as for referring to Hall and Sharples (2003) that variants of food tourism include rural/urban tourism, culinary tourism and gasronomi/cuisine/gourmet tourism.

Karim \& Chi (2010) describe culinary tourism as taking account of all tourist activities related to food experience in a destination. Whereas Long (1998) define culinary tourism as "the pursuit of unique and memorable culinary experience of all kinds, often while travelling, but one can also be a culinary tourist at home". In 2004, long improving the definition so that culinary tourism is also about the host destinations that utilize food to showcase their cultures and histories, by making the food marketable and thus representing an attractive local identity for visitors. The term culinary tourism is selected and defined as a tourism trip, during which the consumption or experience of local food and beverages is expressed in various food-related activities, regardless of whether experiencing local food is or is not a primary purpose for travel (Yun et al., 2011). Hall and Sharples (2003) states that culinary tourism includes visitation to traditional market, local restaurant, and food festival while visit a tourist destination.

The definition implies that it is about visitors who are eager to discover food that is novel to them as well as to explore the new culture linked to the food. This exploration is related to the knowledge or information transfer about the people, culture, traditions, and identity of the place visited. Culinary tourist 
every so often eats and consumes local food and beverages while they visit a destination (Shenoy, 2005). When travelling, visitors engage in some form of dining (Chang, Kivela, \& Mak, 2011). In experiencing culinary tourism, tourists are affected by internal factors such as demographics, travel intention, length of visit, types of travel group - individual or group (Woodside and Dubelaar, 2002). Evidence from a number of studies suggests that visitor interests in and preferences for food in destination settings can have a significant influence on their destination choices (Hall \& Sharples, 2003).

Long (2004) state that "intensity, exploratory participation in the foodways of another - participation including the consumption, preparation-on, and presentation of a food item, cuisine, meal system, or eating style considered to belong to a culinary system not one's own". The need for food and drink to encourage the manager to establish some restaurants, canteens or the like with a wide selection of offerings, especially the distinctive patterned Cirebon, like Nasi jamblang and Empal Gentong (Jaelani, 2016). Food to be a "cultural artifact (Scarpato, 2002), food is a cultural practice distinguishing one culture from another (Boniface, 2003). Local food as the indigenous food and drink that is grown and produced locally and reflects local identity. (Coit, 2008), the term local can also refer to certain geographic places, such as food grown within a particular state or region. (Nummedal and Hall, 2006).

In conducting culinary tourism, tourist being affected by internal factors such as demographics, travel intention, length of stay, types of travel - individual or in group (Woodside and Dubelaar, 2002).

Social theorists and empiricists studying food consumption have generally looked at the influence of socioeconomic and demographic variables on dining out, frequency of eating out, money spent on food at home and outside the home. All these empirical studies reveal the significance of socio-economic and some demographic variables in food consumption away from home (Shenoy, 2005). He defines culinary tourist eats and consumes local food and beverage at the destination.

Based on the literature review, this research used the theory from Hall and Sharples to in order to study the culinary tourism phenomenon in Cirebon as depicted in Figure 1.

Fig. 1. Research Framework

\section{METHOD}

This study was conducted with the intention to look at the phenomenon of culinary tourism in Cirebon, particularly from the perspectives of city visitors using explorative research method. Data was collected using questionnaires which consisted of characteristics of respondents and culinary tourism phenomenon from respondents' point of view.

Of 100 questionnaires distributed to visitors of the city of Cirebon using incidental sampling technique, 80 were back where visitors responded to questions about the phenomenon of culinary tourism in Cirebon that include sub variables of visitation to traditional market, food festival and local restaurant.
Data collected were analyzed descriptive method using statistical calculation such as frequency, mean value and standard deviation. The findings that resulted from this study were then presented, discussed, and concluded.

\section{RESULT AND DISCUSSION}

\section{Characteristics of Respondents}

The respondents' characteristics were the information concerning their gender, age, education background, occupation, origin, marital status, income, expenses, types of tourism, purpose of visit Cirebon, frequency of food hunting, favorite food, media to get info about the food, purpose of visiting culinary place, the chosen place to try Cirebon food.

TABLE I. RESPONDENTS' OPINION ABOUT CULINARY TOURISM

\begin{tabular}{lcc}
\hline \multicolumn{1}{c}{ Description } & Mean Value & Meaning \\
\hline Frequency to buy local food at food street? & 3.17 & sometimes \\
You like to eat food in the restaurant which serves local food only. & 3.39 & Neutral \\
How often do you buy food and drink in the culinary festival? & 2.81 & sometimes \\
Do you agree that eating local food is your daily activity? & 3.53 & agree \\
How often do you buy local food when you go travelling? & 3.52 & 3.99 \\
Do you agree that tasting typical food in Cirebon is the main purpose of visiting Cirebon? & 3.53 & Agree \\
How often do you try typical food in Cirebon? & 3.40 & often \\
How often do you buy and consume local product when you visit Cirebon? & 3.35 & Sometimes \\
How often do you buy typical food in Cirebon for souvenir? & \\
\hline
\end{tabular}


Out of the total number of 75 respondents, $75.7 \%$ of them were male, whereas $24.3 \%$ were male. Of the respondents, $41.3 \%$ obtained four-year diploma / Bachelor's degree, $24 \%$ finished at senior high school, $18.7 \%$ did a post graduate degree, and $13.3 \%$ had three-year diploma. Regarding their age, $30.7 \%$ of them were between $45-55,24 \%$ were between $25-35,20 \%$ were between $35-45,18.6 \%$ below 25 , and only 6. \&\% above 55 years of age. The majority of respondents were married $(66.2 \%$ of the respondents) and spent $40-60 \%$ of their income for food ( $41 \%$ of the respondents). The majority of respondents or $49.3 \%$ worked as employees in private sectors, only $18.7 \%$ worked as civil servant. Most of respondents' domicile (76\%) were outside Cirebon, only $24 \%$ were residing in Cirebon.

Among the visitors of Cirebon, the purpose of visit was mainly for culinary tourism (58\%), followed by nature tourism (29.3\%), and the minority was for cultural tourism and marine tourism. The majority of visitors or $48.6 \%$ have ever been to Cirebon $2-5$ times, $37.8 \%$ more than $37.8 \%$, and only $13.5 \%$ came to Cirebon for the first time. The purpose of visit was mainly for vacation $(41.3 \%)$, followed by business purpose $(28 \%)$ and culinary $(14.1 \%)$. However, no matter what purpose the respondents had when visiting Cirebon, the majority $(97.3 \%)$ of respondents took time to taste the typical food in Cirebon. The most favorite food was Empal Gentong, chosen by $72 \%$ of respondents), followed by Nasi Jamblang (21.3\%). The majority of Respondents received the information about typical food in Cirebon from social media $(54.7 \%$. The next source of information was communication media such as telephone to communicate with friends and relatives. The majority of respondents (44\%) went to restaurant/café to taste the food. The next favorite place was street food vendor $(21.3 \%)$, followed by traditional market $(14.7 \%)$. When they visit places to eat, their main purpose was for culinary tourism (60\% of respondents), followed by the purpose of business meal $(14.7 \%)$

TABLE II. LIKERT SCALE AND INTERPRETATION

\begin{tabular}{lll}
\hline Scale & \multicolumn{1}{c}{ MEANING } & \multicolumn{1}{c}{ Mean Range } \\
\hline 5 & $\begin{array}{l}\text { Usually / Strongly } \\
\text { agree }\end{array}$ & $4.21-5.00$ \\
4 & $\begin{array}{l}\text { Often / Agree } \\
3\end{array}$ & $3.41-4.20$ \\
3 & Sometimes / Neutral & $2.61-3.40$ \\
2 & Seldom / Disagree & $1.81-2.60$ \\
1 & $\begin{array}{l}\text { Never / Strongly } \\
\text { disagree }\end{array}$ & \\
& &
\end{tabular}

\section{Culinary Tourism}

The second part of the questionnaire concerned the respondents' response related to culinary tourism. There were 9 questions for them, and they had to indicate their answers on the five Likert scales and interpreted as in Table I. The result in terms of mean value and interpretation can seen in Table 2 .

The result showed that the visitors of Cirebon sometimes buy local food at Food Street, and they also quite like to eat food in the restaurant which serves local food only. They sometimes buy food and drink in the culinary festival and agree that eating local food is their daily activity. They often buy local food when they go travelling and agree that tasting typical food in Cirebon is the main purpose of visiting Cirebon. They often try typical food in Cirebon, sometimes buy and consume local product when they visit Cirebon, and sometimes buy typical food for souvenir.

\section{CONCLUSION AND RECOMMENDATION}

The majority of visitors to Cirebon under study was women, obtained bachelor's degree, at the age of $35-45$, worked as a private employee, spending $40-60 \%$ of their income for food, and frequent visitors to Cirebon. They came to Cirebon for various purpose, such as vacation, business purpose and culinary. However, whatever their purpose was, they took time to taste local food, and the most favorite food was Empal Gentong. They even agree that eating local food was their rgular activity when they visited Cirebon. They prefer visiting restaurant instead of street food vendor and traditional market. Food festival was not frequently mentioned for culinary activity because it was not always available. Social media was the respondents' main source of information to get information about food and place to eat in Cirebon.

In order to support culinary tourism in Cirebon, it is suggested that food festivals to be held regularly, information sharing of events in social media should be increased, and further research about culinary tourism with wider number of respondents should be conducted.

\section{REFERENCES}

Chang, R. C. Y., Kivela, J., \& Mak, A. H. N. (2011). Attributes that influence the evaluation of travel dining experience: When East meets West. Tourism Management, 32(2), 307-316. doi: 10.1016/j.tourman.2010.02.009

Coit, M. (2008). Jumping on the next bandwagon: An overview of the policy and legal aspects of the local food movement. Journal of Food Law \& Policy, 4, 45-70

Hall, M. C., \& Sharples, L. (2003). The consumption of experiences or the experience of consumption? An introduction to the tourism of taste. In M. C. Hall, L. Sharples, R. Mitchell, N. Macionis \& B. Cambourne (Eds.), Food tourism around the world: Development, management and markets (pp. 1-24). Oxford and Burlington: Butterworth-Heinemann.

Jaelani, Aan. Edy Setyawan and Nursyamsudin Hasyim (2016), Religious Heritage Tourism and Creative Economy in Cirebon: The Diversity of

Religious, Cultures and Culinary,State Institute of Islamic Studies (IAIN) Syekh Nurjati Cirebon, Retrieved from https://mpra.ub.uni-muenchen.de/70145/ MPRA Paper No. 70145, posted 20 March 2016 20:58 UTC

Karim, S. A., \& Chi, C. G.-Q. (2010). Culinary tourism as destination attraction: An empirical examination of destinations' food image. Journal of Hospitality Marketing \& Management, 19(6), 531-555. doi: 10.1080/19368623.2010.493064 
Long, L. M. (1998). Culinary Tourism: A Folkloristic Perspective on Eating and Otherness. Southern Folklore, 55(3), 181-204.

Long, L. M. (2004). Culinary tourism. Kentucky: The University Press of Kentucky
Nummedal, M., \& Hall, M. C. (2006). Local food in tourism: An investigation of the New Zealand South Island's bed and breakfast sector's use and perception of local food. Tourism Review International, 9, 365-378. doi: $10.3727 / 154427206776330571$ 